\title{
Major Adverse Cardiovascular Events: An Inevitable Outcome of ST-elevation myocardial infarction? A Literature Review
}

\author{
Ishan Poudel $^{1}$, Chavi Tejpal $^{2}$, Hamza Rashid $^{3}$, Nusrat Jahan ${ }^{1}$ \\ 1. Internal Medicine, Department of Research, California Institute of Behavioral Neurosciences and Psychology, \\ Fairfield, USA 2. Family Medicine, Department of Research, California Institute of Behavioral Neurosciences and \\ Psychology, Fairfield, USA 3. Internal Medicine: Critical Care, Department of Research, California Institute of \\ Behavioral Neurosciences and Psychology, Fairfield, USA
}

Corresponding author: Ishan Poudel, ishanpoudel@gmail.com

\begin{abstract}
Major adverse cardiovascular events (MACE) remain the major cause of mortality and morbidity in patients with STEMI (ST-elevation myocardial infarction). The current literature is aimed to analyze the occurrence of MACE following STEMI irrespective of treatment provided, and follow up after the first diagnosis of STEMI. A PubMed search for Studies of STEMI identified 24,244 articles. After applying our inclusion/exclusion criteria, we found out 75 articles of relevance wherein MACE and its components were considered to be the primary endpoint. These 75 articles included eight Cohort Studies, 13 clinical trials including five randomized controlled trials (RCT), one case-control Study, one cross-sectional study, one review article, and 51 other observational studies. Our analysis shows that MACE remains one of the strongest adverse outcomes among STEMI patients. The current literature review found out the incidence of MACE was $4.2 \%$ to $51 \%$ irrespective of the mode of treatment, and follow-ups lasting up to 10 years from the time of STEMI diagnosis.
\end{abstract}

Categories: Cardiology, Family/General Practice, Internal Medicine

Keywords: stemi, stemi major adverse cardiovascular events, stemi complications, stemi review

\section{Introduction And Background}

ST-elevation myocardial infarction (STEMI) has multiple definitions proposed over time and most of them can inclusively be defined as symptoms of ischemia of the myocardium that presents with the classical electrocardiographic change of elevation of ST-segment at I point and positive cardiac biomarkers above the accepted blood level [1]. Electrocardiographically STEMI can be defined as ST-elevation (STE) of $\geqslant 1 \mathrm{~mm}$ at the J point in 2 contiguous chest and limb leads excluding V2-V3, which must be $\geqslant 2 \mathrm{~mm}$ in men or $\geqslant 1.5 \mathrm{~mm}$ in women [2].

Received 07/08/2019

Review began 07/15/2019 Review ended 07/16/2019 Published 07/30/2019

๑) Copyright 2019

Poudel et al. This is an open access article distributed under the terms of the Creative Commons Attribution License CC-BY 3.0., which permits unrestricted use, distribution, and reproduction in any medium, provided the original author and source are credited.
Major adverse cardiovascular events (MACE) has no concrete definition, but over time various definitions have been used in cardiovascular research with MACE selected as primary or secondary end-point. It has been defined by various authors since mid-1990 to include an overlapping range of adverse events [3,4]. Multiple adverse events included in different research as a component of MACE are heart failure, non-fatal re-infarction, recurrent angina pain, re-hospitalization for cardiovascular-related illness, repeat percutaneous coronary intervention (PCI), coronary artery bypass grafting and all-cause mortality [5]. MACE can also include unscheduled coronary revascularization, stroke, re-infarction and all-cause death and mortality [6]. MACE with myocardial infarctions have been assessed in the past and multiple articles have been published regarding specific percentage of patients having MACE after particular medical management or after undergoing certain procedures (like PCI) for both STEMI and NSTEMI. The aim of the study is to quantify the available data on the risk of MACE in patients with STEMI irrespective of the mode of management.

\section{Review}

\section{Method}

Literature was searched in PubMed with parallel strategies based on MeSH subheadings and regular keywords for data collection. Table 1 shows regular and MeSH keywords for literature search. 


\section{Cureus}

Regular keyword-STEMI

Total Records

Records selected

1800

Regular keyword- STEMI Major Adverse Cardiovascular Events

Total records

1277

Records selected

178

MeSH Keyword STEMI (Subheading- Complications)

Total records

276

Records selected

87

TABLE 1: Regular and MeSH keywords for literature search.

Studies were selected after applying the following Inclusion/Exclusion Criteria

Inclusion Criteria

1. Human subjects of age $45+$ years

2. Diagnosis of STEMI have positive EKG

3. Paper published in English language and within the past 5 years

4. The study types were observational studies, clinical trial including randomized controlled trial, cohort study, case-control study or review article

5. All full papers

Exclusion Criteria

1. Animal Studies

2. Non- English language literature

3. Meta-analysis, case report and case series study

\section{Results}

Table 2 shows the total number of articles after applying inclusion/exclusion criteria in the following order 


\section{Cureus}

Regular keyword-STEMI

Total Records

22691

Inclusion/Exclusion

Humans

19128

English Language

17286

Published Within 5 years

6066

Patient Age 45+ years

4518

Full Text online

1800

Regular keyword- STEMI Major Adverse Cardiovascular Events

Total records

Inclusion/Exclusion

Humans

English language literature

1031

Published within 5 years

529

Patient age $45+$ years

455

Full Text online

178

\section{MeSH Search MeSH Keyword STEMI (Subheading - Complications)}

Total records

Inclusion/Exclusion

Humans

English language literature

259

Published within 5 years

Age $45+$ years

TABLE 2: Total number of articles after applying inclusion/exclusion criteria

A total of 1622 articles from keyword search 'STEMI' were excluded due to lack of outcome of interest "Major Adverse Cardiovascular Events" and removal of duplicates. After a refined search, the total number of articles obtained was 178 free full texts. All 178 free full texts were reviewed and 103 were removed due to one of the following reasons:

- Not specifying the disease of interest (those which did not assess for STEMI separately but were rather a composite assessment of STEMI with NSTEMI or ACS as a whole or both)

- Case Report or Case Series Studies (as it only assessed for a particular patient in focus)

- Meta-analysis

- Data Extraction not possible by quality assessment.

Finally, 75 publications in PubMed (with free full text available online) were reviewed, which included:

- 51 observational studies, among which one specifically identified itself as a prospective observational 
study.

- Five studies that identified themselves as RCT and eight other studies that identified themselves as clinical trials [7-19].

- Eight studies identified as Cohort (including two identified as a retrospective cohort and five identified as a prospective cohort) [20-27].

- One study identified as a cross-sectional study ( $\mathrm{n}=1244)$

-one as case-control study and

-one as a review article [28-30].

The maximum number of subjects in a study was 15,628 and the minimum was 8 , and the total number of subjects included in all 75 studies was 77,782 [31,17]. Among all 75 studies, 62 studies explained percutaneous coronary intervention (PCI) either as the intervention of choice or as a primary intervention inclusive of other management strategies. Coronary angiography was explained as the investigation of choice in four studies $[9,32-34]$.

All the records reviewed were freely available for review and the citations for the borrowed definitions are available. A qualitative review was performed on the available records after Inclusion/Exclusion to include the relevant disease and population with the required outcome.

The figure below shows the flowchart with the process of current literature review (figure 1).

\section{Flow chart}

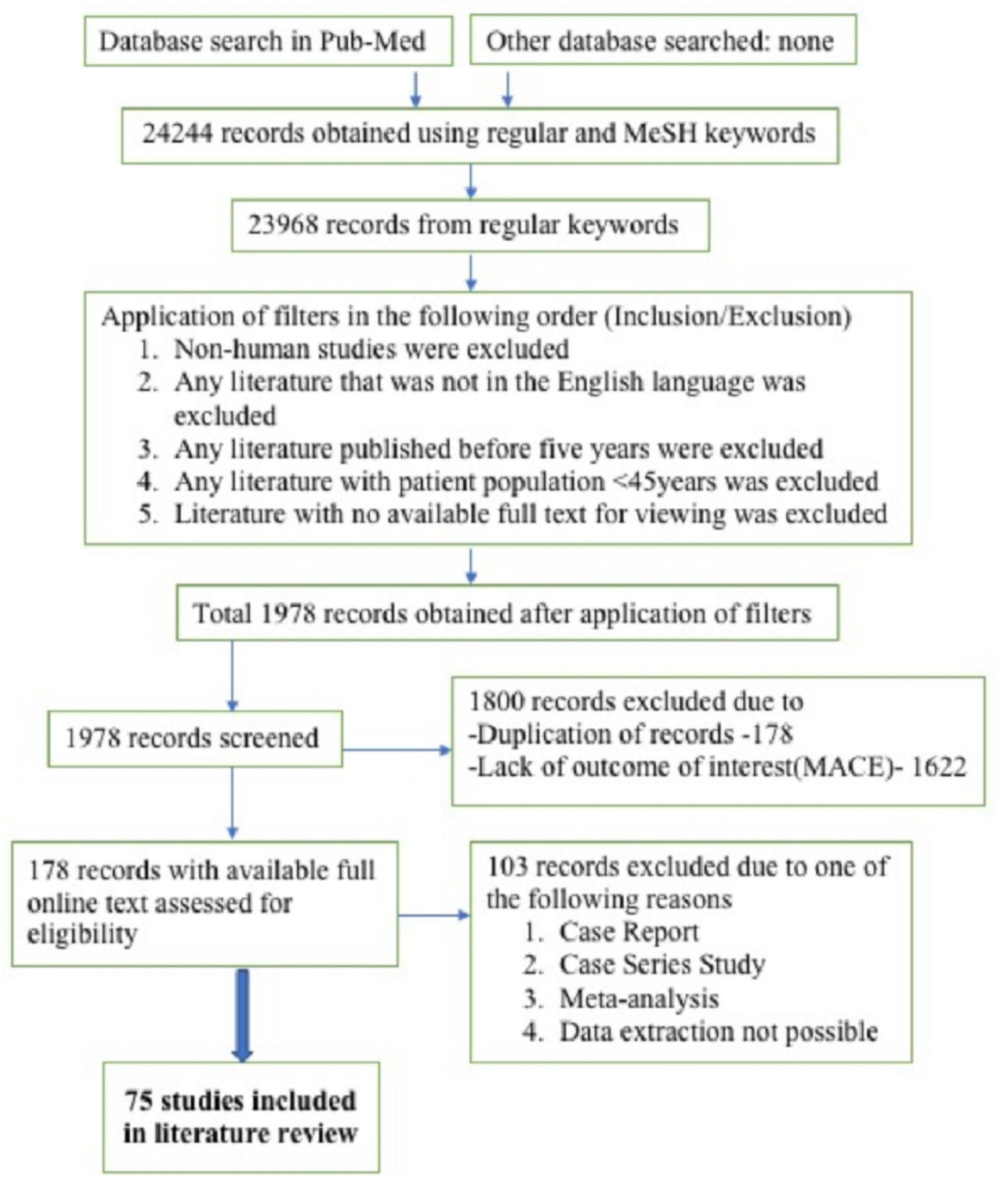




\section{Cureus}

FIGURE 1: Flow chart showing the process of current literature review

\section{Discussion}

The analysis performed was aimed at demonstrating how STEMI was related to MACE irrespective of the management strategy. Though MACE was observed with all the modalities of management for STEMI, the strength of association was not assessed. We firmly believe that there are large variations in the number of MACE events when clearly analyzed for different modalities of treatment. We also found out that MACE incidence depends upon the pre-STEMI health status, age, gender, race, co-morbidities of the patient and many other factors which are not yet explored.

The endpoint of study was major adverse cardiovascular outcome which was explained in the reviewed literature as combination of at least one or more of: all-cause mortality/death (37 studies), re-infarction (25 studies), cardiovascular mortality/death (23 studies), repeat revascularization (18 studies), stroke (16 Studies), heart failure (14 studies), non-fatal re-infarction (11 studies), stent thrombosis (eight studies), major bleeding (seven studies), microvascular obstruction (five studies), re-hospitalization for cardiovascular-related illness (four studies), repeat PCI (four studies), non-cardiovascular mortality/death (two studies) and transient ischemic attack (one study)[7-45].

Table 3 summarized some of the studies with MACE reported from selected data for the literature review: 


\section{Cureus}

\begin{tabular}{|c|c|c|c|c|c|}
\hline $\begin{array}{l}\text { Author/ } \\
\text { Date }\end{array}$ & Study Design & Population with STEMI & $\begin{array}{l}\text { Sample } \\
\text { Size }\end{array}$ & Main Points & $\mathrm{p}$-value \\
\hline $\begin{array}{l}\text { Lee et al. } \\
\text { [35],2017 }\end{array}$ & $\begin{array}{l}\text { Observational } \\
\text { Study }\end{array}$ & $\begin{array}{l}363 \text { patients with anemia and rest of them with no } \\
\text { anemia (between 2005-2014) }\end{array}$ & 1751 & $\begin{array}{l}\text { MACE was } 33.8 \% \text { vs } 22.9 \\
\% \text { in anemia and non- } \\
\text { anemia group respectively }\end{array}$ & $P<0.001$ \\
\hline $\begin{array}{l}\text { Liu et al. } \\
{[36], 2015}\end{array}$ & $\begin{array}{l}\text { Observational } \\
\text { Study }\end{array}$ & $\begin{array}{l}\text { Follow up with serum apelin levels for patients who } \\
\text { underwent } \mathrm{PCI}\end{array}$ & 120 & $\begin{array}{l}34.3 \% \text { patients in the low } \\
\text { apelin group compared to } \\
13.3 \% \text { in high apelin group } \\
\text { had MACE }\end{array}$ & N/A \\
\hline $\begin{array}{l}\text { Li et al. } \\
\text { [28],2017 }\end{array}$ & $\begin{array}{l}\text { Multicenter } \\
\text { Cross- } \\
\text { Sectional } \\
\text { Study }\end{array}$ & $\begin{array}{l}607 \text { patients (June } 2009 \text { - June 2010) and } 637 \\
\text { patients (2015) from hospitals in Northeast China }\end{array}$ & 1244 & $\begin{array}{l}\text { No significant change in } \\
\text { MACE [13.34\% vs. } 13.66 \%] \\
\text { in } 5 \text { years }\end{array}$ & $\begin{array}{l}P= \\
0.872\end{array}$ \\
\hline $\begin{array}{l}\text { Yu et al. } \\
{[37], 2017}\end{array}$ & $\begin{array}{l}\text { Observational } \\
\text { Study }\end{array}$ & $\begin{array}{l}\text { Patients who underwent } \mathrm{PCl} \text { with a mean age of } 59.1 \\
\text { years }\end{array}$ & 323 & $\begin{array}{l}\text { MACCE occurred in } 38 \\
\text { patients }(12 \%)\end{array}$ & N/A \\
\hline $\begin{array}{l}\text { Cheng et } \\
\text { al. } \\
{[27], 2014}\end{array}$ & Cohort Study & $\begin{array}{l}\text { Patients treated with primary } \mathrm{PCl} \text { followed by } \\
\text { measurement of triglyceride (TG) }\end{array}$ & 247 & $\begin{array}{l}\text { The fewer occurrence of } \\
\text { MACE with lower TG } \\
\text { compared to higher TG } \\
\text { levels }(26.1 \% \text { vs. } 11.9 \%)\end{array}$ & $\begin{array}{l}p= \\
0.0137\end{array}$ \\
\hline $\begin{array}{l}\text { Grundeken } \\
\text { et al. } \\
\text { [38],2017 }\end{array}$ & $\begin{array}{l}\text { Observational } \\
\text { Study }\end{array}$ & $\begin{array}{l}\text { Patients with bifurcation }(n=123) \text { and non-bifurcation } \\
(n=842) \text { lesion undergoing PCI with self-apposing- } \\
\text { stents. }\end{array}$ & 965 & $\begin{array}{l}\text { MACE ( } 8.7 \% \text { vs. } 8.4 \%) \text { in } \\
\text { bifurcation vs. non- } \\
\text { bifurcation lesion. }\end{array}$ & N/A \\
\hline $\begin{array}{l}\text { Reinstadler } \\
\text { et al. } \\
\text { [13],2016 }\end{array}$ & Clinical Trial & $\begin{array}{l}792 \text { STEMI patients re-perfused within } 12 \mathrm{hrs.} \mathrm{of} \\
\text { symptom onset followed up for } 12 \text { months for MACE } \\
\text { which included } 540(68 \%) \text { patients with antecedent } \\
\text { hypertension }\end{array}$ & 792 & $\begin{array}{l}\text { MACE with hypertensive } \\
\text { patient vs non-hypertensive } \\
\text { was [ } 45 \text { patients vs eight } \\
\text { patients] }\end{array}$ & $\begin{array}{l}\mathrm{p} \text {-value } \\
<0.01\end{array}$ \\
\hline $\begin{array}{l}\text { Nakashima } \\
\text { et al. } \\
\text { [39],2017 }\end{array}$ & $\begin{array}{l}\text { Observational } \\
\text { Study }\end{array}$ & $\begin{array}{l}\text { Patients with primary } \mathrm{PCl} \text { including } 212 \text { patients with } \\
\text { MI onset in the morning. }\end{array}$ & 663 & $\begin{array}{l}\text { MACE was higher with } \\
\text { morning onset of MI } \\
\text { compared to other MI onset } \\
\text { at other time }[21 \% \text { vs } 4 \%]\end{array}$ & $\mathrm{p}=0.012$ \\
\hline $\begin{array}{l}\text { Li et al. } \\
{[40], 2018}\end{array}$ & $\begin{array}{l}\text { Observational } \\
\text { Study }\end{array}$ & $\begin{array}{l}\text { Patients with primary PCI with Drug-Eluting Stent } \\
\text { either with Trans-Radial Intervention(TRI) or with } \\
\text { Trans Femoral Intervention(TFI) }\end{array}$ & 689 & $\begin{array}{l}\text { After propensity score } \\
\text { matching the incidence of } \\
\text { MACE was TFI > TRI } \\
{[11.6 \% \text { vs. } 4.6 \%]}\end{array}$ & $\begin{array}{l}\mathrm{p} \text {-value } \\
\text { of } 0.018\end{array}$ \\
\hline $\begin{array}{l}\text { Park et al. } \\
\text { [41],2016 }\end{array}$ & $\begin{array}{l}\text { Observational } \\
\text { Study }\end{array}$ & $\begin{array}{l}\text { Patients with STEMI from INTERSTELLAR STEMI } \\
\text { registry who underwent PCI were analyzed for follow } \\
\text { up period of } 2.2 \pm 1.6 \text { years }\end{array}$ & 668 & $\begin{array}{l}\text { MACCE } 14.1 \%(9.7 \% \\
\text { MACCE and } 5.2 \% \text { all-cause } \\
\text { mortality })\end{array}$ & N/A \\
\hline $\begin{array}{l}\text { Kołtowski } \\
\text { et al. } \\
\text { [7],2016 }\end{array}$ & $\begin{array}{l}\text { Randomized } \\
\text { Control Trial }\end{array}$ & $\begin{array}{l}\text { Patients from OCEAN trial undergoing PCI with radial } \\
\text { ( } n=52) \text { vs. femoral }(n=51) \text { approach. }\end{array}$ & 103 & $\begin{array}{l}\text { In radial vs. femoral group } \\
\text { [9.6\% vs. } 11.8 \%]\end{array}$ & $\mathrm{p}=0.48$ \\
\hline $\begin{array}{l}\text { Reinstadler } \\
\text { et al. } \\
\text { [42],2016 }\end{array}$ & $\begin{array}{l}\text { Observational } \\
\text { Study }\end{array}$ & $\begin{array}{l}\text { Patients undergoing primary } \mathrm{PCl} \text { followed up for } \\
\text { specific period. }\end{array}$ & 200 & $10 \%$ suffered MACE. & $\mathrm{p}=0.001$ \\
\hline $\begin{array}{l}\text { Rajesh et } \\
\text { al. } \\
{[44], 2018}\end{array}$ & $\begin{array}{l}\text { Observational } \\
\text { Study }\end{array}$ & $\begin{array}{l}\text { Follow up for } 314 \text { among total patients who } \\
\text { underwent } \mathrm{PCl} \text { with very long Drug Eluting Stent }\end{array}$ & 343 & $\begin{array}{l}\text { MACE was observed in } 6 \% \\
\text { patients }\end{array}$ & N/A \\
\hline $\begin{array}{l}\text { Lønborg et } \\
\text { al. } \\
\text { [45],2014 }\end{array}$ & $\begin{array}{l}\text { Observational } \\
\text { Study }\end{array}$ & $\begin{array}{l}\text { Patient who underwent PCI. ST peak was analyzed } \\
\text { for every patient. }\end{array}$ & 942 & $\begin{array}{l}\text { ST peak was associated } \\
\text { with a higher rate of MACE } \\
{[26.9 \% \text { vs. } 18.2 \%]}\end{array}$ & $\mathrm{p}=0.002$ \\
\hline
\end{tabular}

TABLE 3: Summary of some of the studies with MACE reported from selected data for the literature review. 
Due to the widespread use of PCI, and least number of papers published with other modes of management as the primary treatment modality for STEMI, the study could not explore much in areas of specific management strategies. MACE occurrence following STEMI is unpredictable, but the rate of occurrence could be minimized with appropriate treatment approach and strategy. More studies are needed to analyze the outcomes of different management strategies in lowering the incidence of MACE. Even with new advanced techniques and technologies, comparisons between the new and old strategies in management should be done in order to find out both long and short-term outcomes.

\section{Conclusions}

The objective of our study is to review the relationship between STEMI and major adverse cardiovascular events irrespective of the treatment modality. The current literature review concluded that MACE remains one of the strongest adverse outcomes in STEMI patients. The incidence of MACE ranges from $4.2 \%$ to $51 \%$ irrespective of the mode of treatment, with follow-up visits ranging from day 0 to 10 years following STEMI. The current literature review has some limitations: the study limits its analysis in terms of age (patients involved were $\geqslant 45$ years old), gender (no gender-specific analysis was performed), modality of treatment, duration of follow up (none of the literature explained the long term follow up $\geqslant 10$ years) and many other unexplored factors which can be tested in future studies.

\section{Additional Information}

\section{Disclosures}

Conflicts of interest: In compliance with the ICMJE uniform disclosure form, all authors declare the following: Payment/services info: All authors have declared that no financial support was received from any organization for the submitted work. Financial relationships: All authors have declared that they have no financial relationships at present or within the previous three years with any organizations that might have an interest in the submitted work. Other relationships: All authors have declared that there are no other relationships or activities that could appear to have influenced the submitted work.

\section{References}

1. O'Gara PT, Kushner FG, Ascheim DD, et al.: 2013 ACCF/AHA guideline for the management of ST-elevation myocardial infarction. Circulation. 2013, 127:10.1161/CIR.0b013e3182742cf6

2. Thygesen K, Alpert JS, Jaffe AS, Simoons ML, Chaitman BR, White HD: Third universal definition of myocardial infarction. Circulation. 2012, 126:2020-2035. 10.1161/CIR.0b013e31826e1058

3. Hermans WRM, Foley DP, Rensing BJ, et al.: Usefulness of quantitative and qualitative angiographic lesion morphology, and clinical characteristics in predicting major adverse cardiac events during and after native coronary balloon angioplasty. Am J Cardiol. 1993, 72:14-20. 10.1016/0002-9149(93)90211-T

4. Keane D, Buis B, Reifart N, et al.: Clinical and angiographic outcome following implantation of the new less shortening wallstent in aortocoronary vein grafts: introduction of a second generation stent in the clinical arena. J Interv Cardiol. 1994, 7:557-564. 10.1111/j.1540-8183.1994.tb00496.x

5. Tsai IT, Wang CP, Lu YC, et al.: The burden of major adverse cardiac events in patients with coronary artery disease. BMC Cardiovasc Disord. 2017, 17:1. 10.1186/s12872-016-0436-7

6. Kacprzak M, Zielinska M: Prognostic value of myeloperoxidase concentration in patients with ST-segment elevation myocardial infarction treated with primary percutaneous coronary intervention. Int J Cardiol. 2016, 223:452-457. 10.1016/j.ijcard.2016.07.258

7. KoL, Filipiak KJ, Kochman J, et al.: Cost-effectiveness of radial vs. femoral approach in primary percutaneous coronary intervention in STEMI - randomized, control trial. Hellenic J Cardiol. 2016, 57:202. 10.1016/j.hjc.2016.06.005

8. Barton GR, Irvine L, Flather M, McCann GP, Curzen N, Gershlick AH, Investigators C: Economic evaluation of complete revascularization for patients with multivessel disease undergoing primary percutaneous coronary intervention. Value Health. 2017, 20:745-751. 10.1016/j.jval.2017.02.002

9. Qi Q, Niu J, Chen T, Yin H, Wang T, Jiang Z: Intracoronary nicorandil and the prevention of the no-reflow phenomenon during primary percutaneous coronary intervention in patients with acute ST-segment elevation myocardial infarction. Med Sci Monit. 2018, 24:2767-2776. 10.12659/MSM.906815

10. Lorenzo ED, Sauro R, Varricchio A, et al.: Randomized comparison of everolimus-eluting stents and sirolimus- eluting stents in patients with ST elevation myocardial infarction: RACES-MI trial. JACC Cardiovasc Interv. 2014, 7:849-56. 10.1016/j.jcin.2014.02.016

11. KoL, Filipiak KJ, Kochman J, et al.: Access for percutaneous coronary intervention in ST segment elevation myocardial infarction: radial vs. femoral-a prospective, randomised clinical trial (OCEAN RACE). Kardiol Pol. 2014, 72:604-11. 10.5603/KP.a2014.0071

12. Lee WC, Wu BJ, Fang CY, et al.: Timing of staged percutaneous coronary intervention for a non-culprit lesion in patients with anterior wall ST segment elevation myocardial infarction with multiple vessel disease. Int Heart J. 2016, 57:417-423. 10.1536/ihj.15-402

13. Reinstadler SJ, Stiermaier T, Eitel C, et al.: Antecedent hypertension and myocardial injury in patients with reperfused ST-elevation myocardial infarction. J Cardiovasc Magn Reson. 2016, 18:80. 10.1186/s12968-0160299-1

14. Park H, Kim HK, Jeong MH, et al.: Clinical impacts of inhibition of renin-angiotensin system in patients with acute ST-segment elevation myocardial infarction who underwent successful late percutaneous coronary intervention. J Cardiol. 2017, 69:216-221. 10.1016/j.jjcc.2016.03.012

15. Eitel I, Pöss J, Jobs A, et al.: Left ventricular global function index assessed by cardiovascular magnetic resonance for the prediction of cardiovascular events in ST-elevation myocardial infarction. J Cardiovasc 
Magn Reson. 2015, 17:62. 10.1186/s12968-015-0161-x

16. Kosmidou I, McAndrew T, Redfors B, et al.: Correlation of admission heart rate with angiographic and clinical outcomes in patients with right coronary artery ST-segment elevation myocardial infarction undergoing primary percutaneous coronary intervention: HORIZONS-AMI (the harmonizing outcomes with revascularization and stents in acute myocardial infarction) trial. J Am Heart Assoc. 2017, 6:10.1161/JAHA.117.006181

17. Kajiwara M, Tanaka A, Kawasaki T, et al.: Safety and efficacy of liraglutide treatment in japanese type 2 diabetes patients after acute myocardial infarction: a non-randomized interventional pilot trial. J Cardiol. 2017, 69:511-517. 10.1016/j.jjcc.2016.10.009

18. Liu X, Hu Y, Huang W, et al.: Soluble ST2 for prediction of clinical outcomes in patients with ST-segment elevation myocardial infarction receiving primary PCI. Int Heart J. 2019, 60:19-26. 10.1536/ihj.18-020

19. Keeley EC, Mehran R, Brener SJ, et al.: Impact of multiple complex plaques on short and long-term clinical outcomes in patients presenting with ST-segment elevation myocardial infarction (from the Harmonizing Outcomes With Revascularization and Stents in Acute Myocardial Infarction [HORIZONS-AMI] trial). Am J Cardiol. 2014, 113:1621-7. 10.1016/j.amjcard.2014.02.016

20. Isik T, Kurt M, Tanboga IH, Ayhan E, Gunaydin ZY, Kaya A, Uyarel H: The impact of admission red cell distribution width on long-term cardiovascular events after primary percutaneous intervention: a four-year prospective study. Cardiol J. 2016, 23:281-8. 10.5603/CJ.a2015.0080

21. Yang L, Zheng T, Wu H, et al.: Predictive value of apelin-12 in patients with ST-elevation myocardial infarction with different renal function: a prospective observational study. BMJ Open. 2017, 7:018595. 10.1136/bmjopen-2017-018595

22. Zhang E, Li Z, Che J, et al.: Anemia and inflammation in ST-segment elevation myocardial infarction. Am J Med Sci. 2015, 349:493-8. 10.1097/MAJ.0000000000000471

23. Ribeiro DRP, Ramos AM, Vieira PL, et al.: High-sensitivity C-reactive protein as a predictor of cardiovascular events after ST-elevation myocardial infarction. Arq Bras Cardiol. 2014, 103:69-75. 10.5935/abc.20140086

24. Hassan AKM, Dimitry SR, Agban GW: Can exercise capacity assessed by the 6 minute walk test predict the development of major adverse cardiac events in patients with STEMI after fibrinolysis?. PloS One. 2014, 9:99035-99035. 10.1371/journal.pone.0099035

25. Wongcharoen W, Sutthiwutthichai S, Gunaparn S, Phrommintikul A: Is non-HDL-cholesterol a better predictor of long-term outcome in patients after acute myocardial infarction compared to LDL-cholesterol? : a retrospective study. BMC Cardiovasc Disord. 2017, 17:10.1186/s12872-016-0450-9

26. Velibey Y, Parsova EC, Ceylan US, et al.: Outcomes of survivors of ST-segment elevation myocardial infarction complicated by out-of-hospital cardiac arrest: a single-center surveillance study. Turk Kardiyol Dern Ars. 2019, 47:10-20. 10.5543/tkda.2018.32657

27. Cheng YT, Liu TJ, Lai HC, et al.: Lower serum triglyceride level is a risk factor for in-hospital and late major adverse events in patients with ST-segment elevation myocardial infarction treated with primary percutaneous coronary intervention- a cohort study. BMC Cardiovasc Disord. 2014, 14:143. 10.1186/14712261-14-143

28. Li GX, Zhou B, Qi GX, et al.: Current trends for ST-segment elevation myocardial infarction during the past 5 years in rural areas of China's Liaoning province: a multicenter study. Chin Med J . 2017, 130:757-766. 10.4103/0366-6999.202742

29. Liu HW, Han YL, Jin QM, et al.: One-year outcomes in patients with ST-segment elevation myocardial infarction caused by unprotected left main coronary artery occlusion treated by primary percutaneous coronary intervention. Chin Med J. 2018, 131:1412-1419. 10.4103/0366-6999.233948

30. van Kranenburg M, Magro M, Thiele H, et al.: Prognostic value of microvascular obstruction and infarct size, as measured by CMR in STEMI patients. JACC Cardiovasc Imaging. 2014, 7:930-9. 10.1016/j.jcmg.2014.05.010

31. Gruberg L, Hellkamp AS, Thomas LE, et al.: The association of previous revascularization with in-hospital outcomes in acute myocardial infarction patients: results from the national cardiovascular data registry. JACC Cardiovasc Interv. 2015, 8:1954-1962. 10.1016/j.jcin.2015.08.030

32. Akkus, $\mathrm{O}$, Topuz $\mathrm{M}$, Koca $\mathrm{H}$, et al.: The relationship between low thiol levels and major adverse cardiovascular events after primary percutaneous coronary intervention in patients with STEMI. Turk Kardiyol Dern Ars. 2018, 46:248-259. 10.5543/tkda.2018.82668

33. Deng F, Zhao Q, Deng Y, et al.: Prognostic significance and dynamic change of plasma macrophage migration inhibitory factor in patients with acute ST-elevation myocardial infarction. Medicine (Baltimore. 2018, 97:12991. 10.1097/MD.0000000000012991

34. Wei P, Fu Q, Tao ZQ, et al.: Relationship between B-type natriuretic peptide and short-term prognosis in non-diabetic patients with ST-segment elevation myocardial infarction. Eur Rev Med Pharmacol Sci. 2016, 20:721-5.

35. Lee WC, Fang HY, Chen HC, et al.: A significant cardiovascular mortality risk after ST-segment elevation myocardial infarction complicated by the comorbidities of hypertension and kidney disease. PloS One. 2017, 12:0180165-0180165. 10.1371/journal.pone.0180165

36. Liu HT, Chen M, Yu J, et al.: Serum apelin level predicts the major adverse cardiac events in patients with ST elevation myocardial infarction receiving percutaneous coronary intervention. Medicine (Baltimore. 2015, 94:449-449. 10.1097/MD.0000000000000449

37. Yu J, Oh PC, Kim M, et al.: Improved early risk stratification of patients with ST-segment elevation myocardial infarction undergoing primary percutaneous coronary intervention using a combination of serum soluble ST2 and NT-proBNP. PloS One. 2017, 12:0182829-0182829. 10.1371/journal.pone.0182829

38. Grundeken MJ, Lu H, Vos N, et al.: One-year clinical outcomes of patients presenting with ST-segment elevation myocardial infarction caused by bifurcation culprit lesions treated with the stentys self-apposing coronary stent: results from the APPOSITION III study. J Invasive Cardiol. 2017, 29:253-258.

39. Nakashima H, Mashimo Y, Kurobe M, Muto S, Furudono S, Maemura K: Impact of morning onset on the incidence of recurrent acute coronary syndrome and progression of coronary atherosclerosis in acute myocardial infarction. Circ J. 2017, 81:361-367. 10.1253/circj.CJ-16-0817 


\section{Cureus}

40. Li H, Rha SW, Choi BG, et al.: Transradial versus transfemoral intervention in ST-segment elevation myocardial infarction patients in Korean population. Korean J Intern Med. 2018, 33:716-726.

10.3904/kjim.2016.316

41. Park SD, Moon J, Kwon SW, et al.: Prognostic impact of combined contrast-induced acute kidney injury and hypoxic liver injury in patients with ST elevation myocardial infarction undergoing primary percutaneous coro- nary intervention: Results from INTERSTELLAR registry. PloS One. 2016, 11:0159416. 10.1371/journal.pone.0159416

42. Reinstadler SJ, Klug G, Feistritzer HJ, et al.: Prognostic value of left ventricular global function index in patients after ST-segment elevation myocardial infarction. Eur Heart J Cardiovasc Imaging. 2016, 17:169-76. 10.1093/ehjci/jev129

43. Abe D, Sato A, Hoshi T, et al.: Drug-eluting versus bare-metal stents in large coronary arteries of patients with ST-segment elevation myocardial infarction: findings from the ICAS registry. J Cardiol. 2014, 64:37783. 10.1016/j.jjcc.2014.02.020

44. Rajesh GN, Sulaiman S, Vellani H, Sajeev CG: One-year clinical outcome of percutaneous coronary intervention with very long ( $\geqslant 40 \mathrm{~mm}$ ) drug-eluting stent. Indian Heart J. 2018, 70:285-289. 10.1016/j.ihj.2018.05.016

45. LØnborg J, KelbH, Engstr $\varnothing \mathrm{m}$ T, et al.: ST peak during percutaneous coronary intervention serves as an early prognostic predictor in patients with ST-segment elevation myocardial infarction. EuroIntervention. 2014, 10:466-474. 10.4244/EIJV10I4A80 